\title{
WOMEN CAREGIVERS, WOMEN WAGE EARNERS
}

\section{Social Pollcy Perspectives in Norway}

\author{
KRIS KISSMAN \\ The University of Michigan, School of Social Work, 4063C Frieze Building, \\ Ann Arbor, MI 48109, U.S.A.
}

\begin{abstract}
Synopsis - This paper assesses the connection between women's political representation and social policies affecting the welfare of the group of individuals most vulnerable to economic impoverishment, single mothers. In general, integrative wage labor and child-care policies are progressing at a faster rate in the small and homogeneous society of Norway as compared to the U.S.A. Norway, however, lags behind other Scandinavian nations in initiating some of the components of comprehensive child care policies, including mothers' allowance, transitional benefit allowance, reduction in the gender gap in earnings, parental leave, day care, child support collection, and income disregard to enable welfare recipients to make successful transition into wage labor. The implications of these findings are discussed in terms of feminist scholarship and activism, which first must impact values and philosophies underlying policy formulations before significant improvements in the welfare of mother-headed families can be accomplished.
\end{abstract}

Norway's 4 million people comprise roughly one-fifth of the total population of Scandinavia. Population size and homogeneity have surely influenced the development of the well-advanced welfare state in Norway. Founded on strong egalitarian values, social policy goals over the last decade have focused on securing a decent level of living for all citizens.

Policies aimed at redistribution of resources are of particular interest to advocates of women's welfare. Female scholars and politicians are striving to expand the concepts of egalitarianism to the creation of a "women-friendly" state in Norway. The ideology on which this type of political system is based, is that harder choices not be forced on women than on men or greater sacrifices when they combine child care and paid work activities (Borhorst \& Sirin, 1986). The goal of creating a state that is responsive to gender-specific issues is important because women do spend a disproportionate amount of time performing unpaid work. Integrative policy developments that focus both on the care functions and labor-force participation of women is a necessary first step in attaining true equality between women and men.

In this paper I will explore how the changing roles of women in Norwegian society are influencing the philosophy and values under- lying social policy formulations. All these changes are very much related to increased political representation on the part of women and their voice in redefining the worldview on which policies are formulated and implemented.

Scandinavian social policies have long reflected strong social responsibility for the welfare of those most vulnerable to economic impoverishment. In the past few years, emphasis is being placed on how this commitment applies to child welfare and labor policies. Norwegian female politicians and scholars alike are contributing a multi-dimensional perspective to various policy areas as these affect the welfare of women as caretakers and women as wage earners. Many of these policies apply to all women caretakers, but I wish to place a special emphasis on how Norwegian child welfare and labor policies affect the subgroup of women who are most vulnerable to impoverishment and marginal social status worldwide, women in motherheaded families.

\section{WOMEN'S POLITICAL REPRESENTATION}

Women's influence within the context of the benevolent Norwegian welfare state could be expected to be considerable. In fact, $35.7 \%$ 
of parliamentary seats were held by Norwegian women in 1989 and eight of 19 Cabinet members are women (Equal Status Council, 1989a). Norwegian women hold the record for the highest political representation in any political system (Skjeie, 1988). Although women have had problems entering the upper echelon of the party systems, eight of Norway's 18 ministers are women (Dahlerup, 1988). The infiltration of women decisionmakers is increasingly evident at all levels of the formerly male-dominated political hierarchy, partly as a result of the Equal Status Act of 1977 , which set the stage for increased representation of female participants. Although the proportion of women on public boards decreases with increased level of task significance, women now hold over $30 \%$ of all public board memberships in Norway (Dahlerup, 1988).

As a result of this high representation and of divergent political views of men and women, Scandinavian politics in general are characterized by gender division on issues relating to the power to define social policy areas (Jones \& Jonasdottir, 1988). Party memberships and loyalties as well as sex define how political issues are dealt with, but women politicians in general have rallied around what has become known in Norway as "organization of life" issues. These issues involve the welfare of women, especially during the life phase when a great deal of energy is devoted to child-rearing activities. This juncture between reproductive and "productive" labor is a critical area of market, state, and family policies. The interconnection between these traditionally distinct policy dimensions has strong bearing on reproductive policies which respond to what is referred to in Norway as the "organization of life" issues.

Not all Norwegian women politicians would consider themselves feminists, but they have, often in collaboration with women scholars, concentrated on defining seemingly gender-neutral areas as gender-specific. Child-welfare poliçies, for example, are really inseparable from labor policies and low wages among women providers. Quality child care is an integral part of comprehensive child-welfare provisions, which must be met in order to allow women entry into wellpaying jobs where they do not have to be preoccupied with lack of good care for their children. Issues like these affect the philosophy and values on which policy decisions are based in a number of ways. The value of caregiving activities may change as women's roles in shaping policies becomes increasingly more potent. Caregiving activities may be elevated to socially necessary labor which should be rewarded (Dahl, 1985).

Women are, for example, dominating social security debates pertaining to income transfers for young mothers, and other issues related to sustenance needs of mothers who are sole providers of their families. Women eligible for public assistance comprise a group of individuals who are divorced, separated, widowed, and never-married. Some of the issues affecting the welfare of these women require that a distinction be made between "women's issues" and equality policies. Equality policies mandating equal pay for equal work do not address such needs as comprehensive child-care policies that create adequate infrastructures for mothers to move from public assistance-recipient status to that of work-force participants.

When gender is identified as a social category for policy initiatives, the boundaries between "family" policies and labor-force policies become diffused. The integration of these traditionally distinct policy areas is desirable because rigid boundaries serve as barriers toward gender equality in the labor market and quality care for children.

\section{WOMEN AS CAREGIVERS}

Caretaking activities can be defined as activities entailed in caring for persons who are unable to take care of themselves, for example, the very young and the very old (Waerness, 1984). In Norway, nearly $90 \%$ of all caretaking, whether we refer to child care or care of the elderly, is performed by women (Leira, 1987a). It is safe to say that this statistic does not vary much across cultures. Caretakers who provide services to the elderly receive partial compensation through local municipalities, and current Norwegian policy debates center around more uniform and larger remuneration for such activities. Here, however, we confine ourselves to the increasing number of single women who have minor 
children, because these women are overrepresented in the poverty population.

One-parent households comprise $17 \%$ of all families in Norway; nearly $90 \%$ of these are mother-headed families and over $70 \%$ of these mothers work full-time (Jensen \& Moen, 1989). Up to $10 \%$ of single parents are estimated to be cohabiting, leaving various figures of the "truly single" ranging from 7\% to $12 \%$ (Jensen \& Moen, 1989; Equal Status Council, 1989b). Over $90 \%$ of single-parent families in Norway receive child support as a result of the state paying the family and then collecting the money from the absentee parent (Hatland, 1984). This process is greatly beneficial to single-headed households in Norway when contrasted with its counterpart in the U.S.A., where only $60 \%$ of single parents receive even partial child-support payments (Rosenfelt \& Stacey, 1987). In addition, all Norwegian custodial parents receive a modest mothers' allowance that is added to the transitional benefits (of those who apply and qualify for such social-security benefits). Transitional benefits in Norway are comparable to Aid to Families with Dependent Children benefits in the U.S.A., except that transitional benefits are a part of the socialsecurity system rather than public-welfare assistance.

Approximately $10 \%$ of single mothers do receive transitional benefit allowances, and this proportion has not increased in the last several years (Hatland, 1984). One of the problems these mothers face is that they are not in a position to determine policies affecting their quality of life. Most recipients of welfare benefits are women, but policy allocations are determined by the male power structure, which has prompted Hernes (1987) to refer to the Norwegian welfare state as patriarchal. Even the comparatively generous Norwegian social-security benefits to single parents (designed to give these providers a choice between staying at home to take care of their children until the youngest child reaches the age of ten, and entering the wagelabor market) seem to be based on patriarchal values about women's activities being limited to caregiving.

Women scholars in Norway are questioning whether income-transfer benefits for single parents, nearly $90 \%$ of whom are women, really do present viable life options. The rela- tively lowered standard of living for single mothers following divorce has been cited as one of the reasons many women are pushed into cohabiting relationships or marriage (Opdahl, 1984). Transitional-benefit allowance is so modest that nearly $9 \%$ of children living in mother-headed households fall below the poverty level (Kamerman \& Kahn, 1988). Although this figure is low compared to the U.S.A., where over $50 \%$ of motherheaded households live in poverty (Danziger, 1989), the relative poverty level is considerable when assessed against Norway's standard of living, which is one of the highest in the world. According to Kjeldstad and Skrede (1988), reproductive issues are not a high priority when it comes to income transfers in Norway. The result is that economic parity between males and females is not realized.

Although the current transitional-allowance policy is a part of social security rather than welfare assistance, it seems to reflect both a low value of caretaker activities, and a 1950 s ideology regarding mothers staying out of the labor force for a lengthy period of time (Klein \& Myrdal, 1956). Single parents who do participate in wage labor to improve their families' quality of life usually lose all benefits, and are often caught in a "poverty trap" where they are not earning a salary adequate to increase their families' standard of living (Hatland, 1984). The current debate in the political arena is between those who claim the need to reduce spiraling social-security expenditures, and the need voiced by feminist politicians to raise the ceiling for income-disregard for working mothers who are entering the labor force. Proposals for policy revisions, spearheaded by feminist advocates, would allow mothers to keep a higher proportion of their benefits while in the process of establishing themselves in the labor market.

\section{WOMEN WAGE EARNERS}

Norwegian women's participation in the labor force is the lowest of all when compared with the Scandinavian countries Sweden and Denmark (Nordic Council, 1983). Only 73\% of Norwegian women between the ages of 20 and retirement age are in the labor force, and half of those work part time (Kvinnor och Man, 1988). Norwegian women also earn 
much lower wages than their counterparts in the other Scandinavian countries, who earn $80 \%$ of male wages. For women in the labor market in Norway, the problem of low wages is comparable to that in the U.S.A. Norwegian women earn $60 \%$ of male wages as compared to $64 \%$ for their U.S.A. counterparts (Warum, 1988; Rosenfelt \& Stacey, 1987). Lower earning capacity can be partly attributed to women being employed in the lowerpaying service sector. However, the proportion of Norwegian women concentrated in the service industry is declining, from $80 \%$ to $50 \%$ in the last decade (Hernes, 1984; Equal Status Council, 1989b) In the U.S., 70\% of employed women are employed in the service sector (Shortridge, 1986).

Sex-based wage differential can also be accounted for by the high proportion of parttime female labor-force participants in Norway. Part-time employment is often seen as positive for women caretakers, however, especially when hourly wages are computed as much higher than the average wage, or $80 \%$ of male wages (Skrede, 1989). In fact, political empowerment of women can partly be attributed to the activities of part-time working women, the "deviants" of dominant labor-market ideology whose life patterns undermine that on which public policies have been based (Hoel, 1984). In Norway, the debate about the dual roles of women is characterized by a search for alternatives to the "all-or-nothing"; full-time career or caretaker activities.

One of these choices involves reforms such as shorter work hours during the phase of life when care of children is increasingly combined with work outside the home. Current proposals for a six-hour work day to ease the burden of dual responsibilities of child-care and wage-labor have been criticized on several grounds. One is that a shorter work day for caretakers has a potential for marginalizing women in the work force, especially those in male-dominated occupations, who already are stratified at the lower level of the occupational hierarchy (Skrede, 1984).

The question of wage compensation represents another major obstacle to attempts to reach consensus on shorter work hours for caretakers, because wage agreements rather than legislation limit the length of work hours (Piven, 1985). The change to a 30-hour work week for caretakers does not appear to be a very radical shift in Norway, where the work week is one of the shortest in all the Western countries. Employed Norwegians worked an average of 36 hours per week in 1985 (Norwegian Official Report, 1987).

Proposals for public transfers through social-security benefits to cover income foregone through shorter work hours have competed with proposals for earlier retirement age. Political division based on age is becoming increasingly evident in Norway, with younger women favoring comprehensive child-care policies, including shorter work hours, longer parental leave, and day care, while older women are concerned with decreasing the current retirement age (Skeije, 1988).

\section{COMPREHENSIVE CHILD CARE POLICIES}

Many of the issues facing single providers are similar to those of two-parent families, particularly the need for a comprehensive infrastructure that allows for real-life options regarding the ways in which dual roles of caretaker and labor-force activities are combined. Although reproductive policies in Norway, including child-support payments, mothers' allowance benefits, child-care and parental leave, are further advanced than in the U.S.A., they lag behind what is happening in other Scandinavian countries. According to Leira (1987b), the history of working mothers in Norway contrasts with that of their counterparts in Sweden and Denmark, where reproductive policies have facilitated the entry of women into the labor market to a larger extent. Day care, for example, has lagged in Norway where municipal child-care is available for only $30 \%$ of children needing child-care as opposed to $60 \%$ in other Scandinavian countries (Leira, 1987a). Single parents in Norway do have a priority on childcare spaces. Proposals for cash allowance for day care in lieu of developing day-care facilities may allow more flexibility for parents in securing places for their children (Bay, 1988).

Along similar lines, parental leave in Norway is among the shortest in all the Scandinavian countries. Norwegian parents have 
up to 168 days per child parental leave, which can be divided between two parents following the birth of a child. Proposals for lengthening parental leave to one year, comparable to policies in Sweden and Denmark, face similar opposition as does a shorter workday for caretakers, particularly with regard to the issue of wage compensation.

\section{CONCLUSION}

The high representation of women in politics in Norway seems inconsistent with the generally slower rate at which comprehensive child-care and labor-force policies are being initiated, compared to other Scandinavian countries. The major contribution of women scholars and politicians seems to have been in changing the philosophy and values on which policies are developed, in face of a relatively conservative political ideology in Norway as compared to Sweden and Denmark. The process of change from rigid dichotomization of policy concerns to a more integrative approach to reproductive and labor policies is evident in various legislative debates regarding shorter work hours and longer parental leave.

The special interest of single providers the group of women most vulnerable to economic impoverishment - may at times be lost because, like their U.S. counterparts, they have rather small representation in the elite feminist scholarship and political arenas. Ideals regarding adequate compensation for caretaker activities compete with values favoring preservation of the two-parent household, with a strong work ethic, and with beliefs supporting compensation for other special interest groups, particularly the elderly. Current proposals for caretaker benefits, for example, do not include an increased benefit package for single providers who stay home to take care of their children. Some suggestions have, however, been made that caretaker activities should be computed in the tabulation of income for old-age benefits (Dahl, 1985).

The three steps toward creation of an egalitarian society set out by the 1977 Norwegian Equal Status Act call for, first, opportunities for women to participate in areas traditionally dominated by men and, second, equal distribution of resources/position for women and men (Norwegian Research Council, 1988). The third step has to do with equal distribution of responsibility, function, and effort in the home.

Norwegian women can be said to be progressing through the first step and lagging behind their counterparts in Sweden and Denmark in the process toward the second step. More equal distribution of resources has a greater impact on caretakers who are not yet in the labor force than does the expansion of opportunity proposed in step one. And step three has little bearing on impoverished single providers, except perhaps as preventative measures that may lead to preservation of marriages and cohabiting lationships. Shared parental responsibilities and other ideological shifts in the "invisible area" of the home can greatly impact the quality of life for working mothers. Equality policies that more closely respond to the needs of sole providers should be based on the expansion of the third step toward equality to encourage absentee fathers to assume greater responsibilities for care of their children.

Policies regulating family functions seem to be far-fetched in spite of the fact that the Norwegian family may indeed have "gone public." Child-support payments, mothers" allowance, and shorter work hours for caretakers do respond to family needs. These policies reflect a women-friendly state and a more just society. But this seems to be as far as policy initiatives can go in responding to needs of women caretakers. Equalization of parental responsibilities will require more ideological rather than legislative changes. The transition toward bi-nuclear families, where absentee fathers retain an active role in providing financial, emotional, and task support to their children, can be expected to be a lengthy process.

Another factor that serves to limit the im. mediate effect of women's scholarship and political representation on the advanced social and economic status of working women is corporate influence. Corporate power has become a central gatekeeper in the Scandinavian state system (Hernes, 1984). According to the author, business and industry have been less willing to recruit women or to take up their issues than the state. Without the cooperation of the corporate sector, or wage- 
labor policies that advocate for the welfare of women workers, the issues of women wage earners, the integration of women into better-paying jobs and caretakers' benefits may be considerably delayed.

Norwegian policies affecting women caretakers and wage earners have many similarities to those found in the U.S.A., where the value of productive work to an even greater extent supersedes the ideology of social responsibility for adequate caretaker compensation. The competition between such benefits as old-age pensions and expenditures for a comprehensive child-welfare program has its parallel in the U.S. The competition between special interests often results in issues affecting the most impoverished and the least vocal group of women, taking second place to that of mothers living in two-parent households. However, comprehensive childcare policies, such as child-support collection, mothers' allowance, proposed parental leave, and income disregard to enable welfare recipients to make a successful transition into wage-labor, are in place or progressing at a much faster rate in Norway than in the U.S.A.

Among the various factors that account for these dissimilarities across cultures, along with population size and homogeneity, is that the philosophy underlying Scandinavian policy development seems to be more integrative and less dichotomized. This is especially true when it comes to issues related to the welfare of women caretakers and wage earners.

\section{REFERENCES}

Bay, A. H. (1988). Penger Eller Barnehageplass: Offentlige Overforinger til smabarnsfamilies [Money or childcare facilities: Public transfer to families with young children]. Oslo: Institutt for Socialforskning.

Borhorst, A., \& Sirin, B. (1986). Women and the welfare state: A new form of political power. In $\mathrm{H}$. Saasoon (Ed.), Women and the welfare state (pp. 165180). London: Hutchinson.

Dahl, T. S. (1985). Womens law. Oslo: Norwegian University Press.

Dahlerup, D. (1988). Nu Er Kominn Timi Til: Leidarvisir fyrir Konur i Stjornmalum [Now is the time: Directions for women in politics]. Kobenhavn: Nordisk Ministerrad.

Danziger, S. (1989). Antipoverty policies and child poverty. Ann Arbor: University of Michigan, School of Social Work, Working Papers Series.
Equal Status Council [Likestillingsradet]. (1989a, December). Milestones in 150 year history of Norwegian women. Oslo, Norway: Author.

Equal Status Council. (1989b). Minifacts on equal rights. Olso, Norway: Author.

Hatland, A. (1984). The future of Norwegian social insurance. Oslo: Institute of Applied Social Research.

Hernes, H. M. (1984). Women and the welfare state: The transition from private to public dependence. In H. Holter (Ed.), Patriarchy in a welfare society (pp. 26-45). Oslo: Norwegian University Press.

Hernes, H. M. (1987). Welfare state \& woman power. Oslo: Norwegian University Press.

Hoel, M. (1984). The female working class. In H. Holter (Ed.), Patriarchy in a welfare society (pp. 106-118). Oslo: Norwegian University Press.

Jensen, A. M., \& Moen, B. (1989). Far og mor, soster og bror [Father and mother, sister and brother]. Tidskrift for Samfunsforsning, 5, 12-21.

Jones, K. B., \& Jonasdottir, A. G. (1988). The political interest of gender. Newbury Park, CA: Sage.

Kamerman, S. B., \& Kahn, A. J. (1988). Mothers alone: Strategies for a time of change. Dover, MA: Auburn House.

Kjeldstad, R., \& Skrede, K. (1988). Intekt og overforinger: mot okt likhet mellom kvinner og menn [Income and transfers: differences and similarities between women and men]. In $R$. Kjeldstad, $H$. Lorentzen, \& A. Ringer (Eds.), Fra Ansvars-Deling til delt ansvar? Artikler om virkemidler og velferd: velfedstaten (Rapport 88:5). Oslo: Institutt for Socialforskning.

Klein, \$., \& Myrdal, A. (1956). Two roles: Home and work. London: Kegan Paul.

Kvinnor och man i norden: Fakta om jamstallheter. (1988). [Women and men in Scandinavia: Facts and equality]. Stockholm: Nordic Council of Ministers.

Leira, A. (1987a). Time for work, time for care: Childcare in a Norwegian setting. In J. Brannen \& $G$. Wilson (Eds.), Give and take in families: Studies in resource distribution. Boston: Allen \& Unwin.

Leira, A. (1987b). Day care for children in Denmark, Norway and Sweden (Rapport 87:5). Oslo: Institutt for Samfunnsforskning.

Nordic Council and Nordic Statistical Secretariat. (1983). Living conditions and inequality in the Nordic countries. Sweden: University of Gothenburg.

Norwegian Research Council for Applied Social Sciences. (1988). Research to promote equal status and gender equality (Programme Memorandum). Oslo: Author.

Norwegian Official Report-NOU9E. (1987). Working hours reforms. Oslo: Norwegian University Press.

Opdahl, N. (1984). Aleneforelderes, levekar og tidsbruk. [Parents alone, life situation use of time]. (Report No. 84-16). Oslo: Central Bureau of Statistics of Norway.

Piven, F. F. (1985). Women and the state: Ideology, power and the welfare state. In A. Rossi (Ed.), Gender and the life course (pp. 265-290). New York: Aldine.

Rosenfelt, D., \& Stacey, J. (1987). Second thoughts on the second wave. Feminist Studies, 13(2), 341-360.

Shortridge, K. (1986). Poverty is a woman's problem. In 
J. Freeman (Ed.), Women: A feminist perspective (pp. 492-501). Palo Alto, CA: Mayfield.

Skjeie, H. (1988). The feminization of power: Norway's political experiment (1984-19?) (Rapport 8/88). Oslo: Institutt for Sosialforskning.

Skrede, K. (1984). Familieokonomi og forsorgerlonn [Family economy and salary of heads of household]. Oslo: Tidsskrift for Samfunnsforskning.

Skrede, K. (1989, July 5-8). Work, family and life-cycle squeezes, the case of Norway. Paper presented at the European Conference of Work and Social Protec- tion: Their Role in the Fight against the Impoverishment of Families in Europe, Brussels.

Waerness, K. (1984). Caring as women's work in the welfare society. In $\mathbf{H}$. Holter (Ed.), Putriarchy in a welfare society (pp. 67-87). Oslo: Norwegian University Press.

Warum, A. M. (1988). Norsk likestilling i Nordisk sammenheng: Likestillingsutviktingen i 1980 ara [Norwegian equality in Scandinavian context: Predictions for equality in the 80's]. Samfunnspeilet, 3, 19-22. 